\title{
O IDEAL DE BRANQUEAMENTO NO PROJETO EDUCACIONAL DE JOSÉ VERÍSSIMO
}

Ricardo Matheus Benedicto*

\begin{abstract}
RESUMO: O presente trabalho tem por objetivo mostrar a importância e o papel desempenhado pelo ideal de branqueamento - que orientou os debates da intelectualidade brasileira sobre a formação da sociedade no século passado - no projeto educacional delineado pelo pensador e literato José Veríssimo Dias de Matos na virada do século XIX para o século XX.
\end{abstract}

Palavras-chave: branqueamento; educação nacional; mestiçagem eugênica; racismo.

RESUMEN: El presente trabajo pretende mostrar la importancia y el papel desempeñado por el ideal de blanqueamiento, que guió a los debates de la intelectualidad brasileña sobre la formación de la sociedad en el siglo pasado, en el proyecto educativo del pensador y literato José Veríssimo Dias de Matos en el pasaje del siglo XIX al XX.

Palabras clave: blanqueamiento; educación nacional; mestizaje eugenésico; racismo.

\section{Introdução}

Neste artigo mostraremos que o ideal de branqueamento do Brasil está presente na obra educacional do literato, escritor e grande representante da intelectualidade brasileira José Veríssimo, A Educação Nacional. Para tanto, na primeira seção, apresentaremos brevemente a política de branqueamento da nação que dominou a primeira metade do século passado. Em seguida, mostraremos que este ideal aparece de forma explícita na obra Estudos Brasileiros de 1889 e nos artigos O País Extraordinário (1899) e Machado de Assis Impressões e Reminiscências (1908) ambos publicados no Jornal do Comércio. Por fim, nossa análise do clássico de Veríssimo evidenciará a tese

\footnotetext{
* Professor Adjunto do Instituto de Humanidades e Letras da Unilab. O artigo é uma adaptação das reflexões realizadas no segundo capítulo de minha tese de doutorado. E mail: ricardomb@unilab.edu.br.
}

enunciada acima, ou seja, que subjacente ao seu projeto educacional se encontra o ideal de embranquecimento dos afro-brasileiros.

\section{A política de branqueamento da nação brasileira}

Com o término da escravidão no Brasil e o advento da República, o projeto de nação delineado e executado pelas elites nacionais, tinha no branqueamento do povo seu ponto central. Convencidas da ideia da inferioridade dos africanos e indígenas as elites políticas e intelectuais do país se perguntavam como resolver o que chamavam de problema negro ${ }^{2}$, a saber, como construir uma nação civilizada - leia-se branca e ocidental - em um país de maioria negra?

\footnotetext{
${ }^{2}$ Veremos adiante que o literato José Veríssimo utilizou esta expressão em artigo publicado no Jornal do Comércio em 1899.
}

BENEDICTO, Ricardo Matheus. O ideal de branqueamento no projeto educacional de José Veríssimo. Revista Sul-Americana de Filosofia e Educação. Número 30: nov./2018-abr.2019, p. 49-63. DOI: https://doi.org/10.26512/resafe.vi3o.28240 
Esta questão foi respondida do ponto de vista teórico com a ideologia do embranquecimento que tinha como sustentáculo a tese de que a mistura de raças tornaria inevitavelmente o país mais branco, e do ponto de vista prático com a política nacional de branqueamento que estava amparada na massiva imigração de europeus.

Esta política e ideologia foram compreendidas corretamente pelo grande pensador afro-brasileiro Abdias do Nascimento que as qualificou acertadamente como genocídio do negro brasileiro. Nascimento mostrou que a ideologia da mestiçagem esconde na realidade a exploração sexual da mulher afro-brasileira bem como o racismo e eurocentrismo embutidos no elogio de um futuro mestiço para Brasil, visto que a miscigenação só é possível se a natureza daqueles implicados no processo for diferente. Nas palavras do autor:

Para a solução deste grande problema a ameaça da "mancha negra" - já vimos que um dos recursos utilizados foi o estupro da mulher negra pelos brancos da sociedade dominante, originando os produtos de sangue misto: o mulato, o pardo, o moreno, o parda-vasco, o homem-de-cor, o fusco, e assim por diante [...] O crime de violação e de subjugação sexual cometido contra a mulher negra pelo homem branco continuou como prática normal ao longo das gerações.

Situado no meio do caminho entre a casa grande e a senzala, o mulato prestou serviços importantes à classe dominante. Durante a escravidão, ele foi capitão-do-mato, feitor, e usado noutras tarefas de confiança dos senhores, e, mais recentemente, o erigiram como um símbolo de nossa "democracia racial". Nele se concentraram a "ameaça racial" representada pelos africanos. E estabelecendo o tipo mulato como o primeiro degrau na escada da branquificação sistemática do povo brasileiro, ele é o marco que assinala o início da liquidação da raça negra no Brasil (NASCIMENTO, 2002, p. 113).

E sobre a política imigratória:

A orientação predominantemente racista da política imigratória foi outro instrumento básico nesse processo de embranquecer o país. A assunção prevalecente, inspirando nossas leis de imigração, considerava a população brasileira como feia e geneticamente inferior por causa da presença do sangue africano. (NASCIMENTO, 2002, p. 115)

Os trabalhos de Abdias do Nascimento (1980, 2002), Elisa Nascimento (2003) Thomas Skidmore (1989) entre outros já trataram de maneira satisfatória do processo de branqueamento do país. No entanto, as recentes pesquisas sobre a origem do racismo e dos modelos tipológicos das sociedades racializadas realizadas pelo antropólogo cubano Carlos Moore faz com que compreendamos de maneira mais adequada as origens deste tipo de política. Moore mostrou em sua obra Racismo ESociedade: novas bases epistemológicas para entender o racismo que diferentemente do que prega o senso comum o racismo não é um produto da modernidade. De fato, como mostrou o intelectual cubano ao longo de seu trabalho a origem do racismo remonta aos primórdios da humanidade. ${ }^{3}$ Desse modo, existiram sociedades racializadas bem antes do advento da modernidade, como a civilização indo-ariana, ibero-americana, ibero-

\footnotetext{
3 Para uma análise similar da origem do racismo ver a obra de Vulindlela Wobogo Cold Wind From the North: The Prehistoric European Origin of Racism Explained by Diop's Two Cradle's Theory, Books on Demand, 2011.
} 
árabe e árabe semita. Para Moore o caráter milenar destas sociedades, que ele considera pigmentocráticas faz com que elas sejam uma das formações de relações raciais mais duráveis na história da humanidade (MOORE, 2007, p. 266). Dito de outro modo, Moore defende que o racismo não se estrutura a partir do conceito biológico de raça, mas é uma construção histórica que tem como dado básico fundamental o fenótipo.

Desmistificado o senso comum sobre o racismo, Moore explica o que é um sistema pigmentocrático. Para o autor, este surge quando um grupo invasor é minoritário e deve organizar sua dominação sobre uma realidade demográfica que ameaça absorvêlo (MOORE, 2007, p. 261). Para evitar a sua extinção, o grupo minoritário, por meio de relações sexuais violentas e organizadas, produziu o que o antropólogo chama de populações brancas de fusão. Estes brancos mulatos também pretendem manter a distância somática do grupo dominado. Em suas palavras:

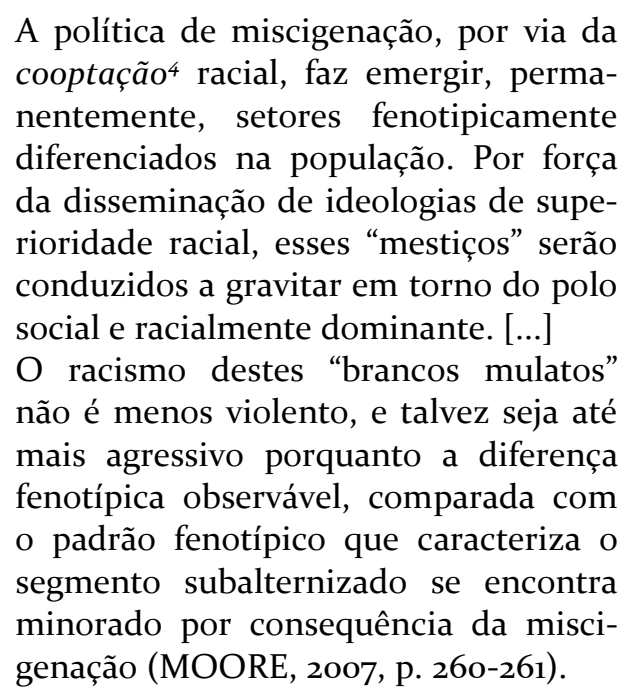

4 Os itálicos são do original.
Moore afirma que neste sistema são as diferenciações da cor da pele, da textura do cabelo, da forma dos lábios e da configuração do nariz que determinam o status coletivo e individual das pessoas na sociedade (MOORE, 2007, p. 260). Assim, o desejo da brancura se origina nestas sociedades porque a camada dominante não é "branca pura”. Como aspiram a este ideal, criam a ilusão de que a mestiçagem produzirá um novo tipo de branco que tomará o seu lugar no concerto da civilização ocidental. Elisa Larkin Nascimento em sua obra $O$ Sortilégio da Cor também chama a atenção para este fato. No entanto, ao invés de caracterizar estes brancos mulatos como populações brancas de fusão, Nascimento os caracteriza como brancos virtuais: a expressão evoca tanto o virtual na acepção de faculdade não realizada, como realidade da era virtual da informática: a imagem ou pulso eletrônico que, apesar de não se conformar num ideal concreto, torna-se real ao gerar efeitos (NASCIMENTO, 2003, p. 113).

E o que o antropólogo cubano traz de novidade na compreensão do branqueamento em sociedades pigmentocráticas? Moore sustenta, acertadamente a nosso ver, que esta política de embranquecimento ancorada na ideologia da mestiçagem é uma política eugênica consciente. Ele nos mostra que carece de fundamento a ideia de que na antiguidade não havia reprodução biológica racialmente seletiva (MOORE, 2007, p. 264). Assim, utilizar a miscigenação como estratégia de dominação não é um fenômeno recente na história da humanidade.

Sobre o modelo ibero-americano de relações raciais o autor assevera: 
Na sua obra O Genocídio do Negro Brasileiro, Abdias do Nascimento (1978) talvez tenha sido o primeiro pensador sul americano a ter enquadrado claramente os preceitos da doutrina da miscigenação na América Latina em uma perspectiva de genocídio [...] tomadas em seu conjunto, essas quatro obras apontam para o fato de que a miscigenação - longe de ser mera inter-relação individual e respeitosa, ditada pela afeição, como é conveniente afirmar - é uma política consciente de eugenia raci-

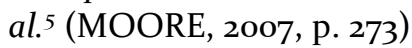

As instituições escolares tiveram um papel decisivo na implementação deste projeto. ${ }^{6}$ Veremos nas próximas seções que José Veríssimo era um defensor da política de embranquecimento da nação bem como as relações entre este ideal de sociedade e o modelo escolar concebido pelo literato.

\section{José Veríssimo e a defesa da política de branqueamento}

José Veríssimo Dias de Matos (18571916) foi um importante crítico literário, historiador e jornalista. Também realizou incursões no campo da Antropologia, Etnografia e Educação. Este paraense publicou originalmente em 1890 a obra - hoje clássica - A Educação Nacional que pretendia oferecer um projeto de educação que contribuísse para que a nascente República brasileira entrasse de forma definitiva no rol das nações civilizadas. Foi diretor de instrução no Pará de 1880 a 1891 ano em que se mudou para o Rio de Janeiro. Na capital do país, lecionou na Escola Normal e no Giná-

\footnotetext{
${ }^{5}$ Os itálicos são do original.

${ }^{6}$ Ver o livro de Jerry Dávila Diploma de Brancura: Política Social e Racial no Brasil 1917-1945. São Paulo: UNESP, 2006.
}

sio Nacional - atual Colégio Pedro II - instituições que viria a dirigir depois (ARAÚJO, 2007, p. 25).

Em sua obra de 1889, Estudos Brasileiros, na qual investigou as possiblidades de uma literatura genuinamente nacional, Veríssimo escreveu:

\begin{abstract}
Para se compreender perfeitamente o espírito de um povo é necessário estudar os diferentes elementos que o compõem. É sobre este critério que assentamos o nosso modo de pensar de que é do estudo bem feito dos elementos étnicos e históricos de compõe o Brasil, da compreensão perfeita do nosso estado atual, de nossa índole, de nossas crenças, de nossos costumes e aspirações que poderá sair uma literatura que se possa chamar conscientemente de brasileira à qual ficará reservado o glorioso destino de fazer entrar este país, pela forte reação de que falamos atrás numa nova via de verdadeira civilização e verdadeiro progresso (VERÍSSIMO, 1889, p. 13). ${ }^{7}$
\end{abstract}

Já sabemos o que a intelectualidade do período concebia como progresso e civilização. Falta, agora, saber o que o intelectual tinha a nos dizer sobre os elementos étnicos formadores do Brasil. Veríssimo considerava que o país foi formado pelos tupis, pelos portugueses e pelos africanos. (p. 9). Sobre estes últimos o pensador paraense sustentava:

Um terceiro elemento étnico veio, passados tempos, trazer-nos fatal contingente. Falamos do elemento africano. Foi o pior dos que tivemos. Raça de uma barbaria estúpida e feroz, as perseguições e atrocidades que sofreu tornaram-na ainda pior do que era. Com esse elemento veio-nos essa terrível coisa chamada escravidão, a que julgamos

\footnotetext{
7 A adaptação ao novo acordo ortográfico foi feita pelo autor.
} 
não errar atribuindo em grande parte o lastimoso estado de nossa sociedade (VERÍSSIMO, 1889, p.10-11). ${ }^{8}$

\section{Veríssimo parece responsabilizar os} africanos pela escravidão e suas funestas consequências na sociedade, visto que afirmou que ela veio com o elemento africano e é em parte responsável pelo lastimoso estado da sociedade. $\mathrm{O}$ autor não apresentou argumentos para sustentar a extrema tese de que o africano é uma raça bárbara, estúpida e feroz o que já é um forte indício do eurocentrismo do educador. Como se não bastasse a virulência acima, Veríssimo prosseguia em sua detração dos africanos:

E como não havia de ser assim se desde o berço até o túmulo, bebendo-lhe o leite, ouvindo-lhe os contos ao serão, folgando com ela, recebendo dela suas crenças fetichistas - essa raça desgraçada e tornada má pela escravidão é nossa companheira e auxiliar? Isto, no entanto, escapou aos nossos literatos que não viram que havia na nossa sociedade alguma coisa pitoresca e alguma coisa atroz a combater (VERÍSSIMO, 1889, p.10-11).

\footnotetext{
${ }^{8}$ José Veríssimo ao escrever esta passagem inseriu a seguinte nota de rodapé: Fui profundamente injusto com a raça negra na qual tenho antepassados. Ela é porventura superior a indígena e prestou ao Brasil relevantes serviços. $\mathrm{O}$ autor provavelmente faz referência ao seguinte trecho escrito em Populações Indígenas e Mestiças da Amazônia: do estudo da língua, das crenças e das tradições populares, aqui, ressalta em toda a evidência a inferioridade deste elemento (negro) e a supremacia das raças indígenas ( $p$. 24). Pena que o intelectual não tenha rejeitado a doutrina da inferioridade africana e indígena e da superioridade europeia. $\mathrm{O}$ que o autor reconsiderou foram os serviços prestados - leia-se escravidão - dos africanos e seus descendentes na formação do Brasil e o local que estes deveriam ocupar na hierarquia racial.
}

Ao ler as palavras de Veríssimo temos a impressão de que os africanos impuseram sua presença no território brasileiro e obrigaram os europeus a se corromperem. Se a escravidão tornou o africano mau, o que dizer dos perpetradores de tamanha barbaridade? Seriam puros cristãos? Bastaria que realizassem o trabalho pesado e estariam livres de tão perversa herança. Sobre a segunda parte da citação, Abdias do Nascimento (2002) argutamente observou que a intelligentsia brasileira sempre procurou tratar a cultura afro-brasileira como exótica, estranha ao contexto brasileiro e como material de laboratório.

De que forma José Veríssimo entendia que essa "coisa atroz" deveria ser combatida? Em artigo publicado no Jornal do Comércio em 1899 é possível obter a resposta à questão:

Não há receio, como supõe, o Sr. Oliveira Lima, de que surja o problema negro no Brasil. Antes de surgir, foi aqui resolvido pelo amor. O cruzamento tirou do elemento negro toda a importância numérica, diluindo-a na população branca. O mulato aqui, desde a segunda geração, quer ser branco, e o branco mesmo, ainda sem deixar-se iludir, e salvo exceções insignificantes, recebe-o, estima-o, liga-se com ele. A mistura de raças tendendo, como asseguram os etnólogos e pode à primeira vista ser reconhecido exato, a fazer prevalecer a superior, acabará forçosamente, em período mais ou menos curto, por extinguir a raça negra daqui. Já vai isso evidentemente acontecendo, e quando a imigração, que penso é o problema capital do Brasil, vier numerosa, apressará, com misturas novas, que aqui se farão sempre, a seleção. Enquanto nos Estados Unidos oito milhões de negros parecem aos seus nacionais brancos um perigo e uma ameaça, contra o qual só lhes antolham meios 
violentos de defesa, aqui ninguém cura deles, que desaparecem simplesmente pelo crescimento da população branca, não pura em sua maioria é verdade, mas cuja mescla vai também ganhando do lado branco e aproximando-se cada vez mais, segundo a regra da antropologia, do tipo superior. Sem nenhum preconceito patriótico, penso, é verdade que tenho razões pessoais para isso, que mais demorada que a americana, a nossa evolução é, se posso dizer assim, mais justa e mais humana. Mesmo nos duros tempos coloniais, não dividíamos jamais a humanidade em duas partes. (VERÍSSIMO, o4 de dezembro de 1899). 9

Tivemos de realizar uma longa citação para que possamos começar a demonstrar o que está enunciado no título desta seção. Além do mais, é importante perceber de que maneira foi, e é, possível escrever um texto com um conteúdo extremamente violento utilizando uma linguagem aparentemente mansa e humanitária. Iniciemos, então, nossa análise do excerto de Veríssimo.

O artigo O País Extraordinário, escrito pelo literato, é uma resenha da obra Nos Estados Unidos - Impressões Políticas e Sociais do intelectual pernambucano Manuel de Oliveira Lima (1867-1928). O pensador paraense discordava de Oliveira Lima quanto à possibilidade de o "problema negro" surgir no Brasil. Como vimos na primeira seção deste artigo, as elites brasileiras debatiam como construir uma nação branca e ocidental em um país de maioria afrobrasileira e indígena. O próprio Veríssimo, no artigo que ora analisamos, explicitamente afirmou: "estou convencido, como o Sr.

\footnotetext{
${ }^{9}$ A adaptação ao novo acordo ortográfico e os itálicos são nossos.
}

Oliveira Lima, que a civilização ocidental só pode ser obra da raça branca, e que nenhuma grande civilização se poderá levantar com povos mestiços." Entendido o "problema negro" - a formulação deste explicita o lugar epistemológico do qual falavam os autores - qual a solução defendida por Veríssimo? O ilustre literato tentou convencer seus interlocutores, que diferentemente dos Estados Unidos, no Brasil a questão seria resolvida com o que chamou de amor. E o que o autor entende por amor? O cruzamento sucessivo das raças com vistas ao branqueamento, ou seja, a mestiçagem eugênica. Esta identificação seria cômica se fosse trágica aos afro-brasileiros.

Não contente com a miscigenação compulsória imposta aos afro-brasileiros de forma paternalista e autoritária, Veríssimo afirmava, sem evidências, que o elemento negro endossava a mistura de raças para tornar-se branco e que estas boas almas os acolhiam em seu meio sem preconceito! $\mathrm{O}$ autor não via preconceito e racismo em um processo cujo corolário levaria à extinção da raça negra! Ademais, se este processo era seguro e querido por todos, visto que prevaleceria o elemento superior, por que sustentava que a imigração europeia era uma necessidade capital? Não havia, neste ponto, uma óbvia contradição? Para arrematar seu discurso "manso" e "humanitário" - sempre em oposição à crueldade da solução norteamericana - asseverava que o Brasil, mesmo durante o período colonial, jamais dividiu a humanidade em duas partes.

É, no mínimo, intrigante que um intelectual do calibre de Veríssimo equipare este processo de extermínio com o amor. Este artigo, que condensa todos os postula- 
dos da política de branqueamento - foi escrito em um jornal de grande circulação, o que mais uma vez evidencia a adesão das elites intelectuais do período a política de embranquecimento, além de nos mostrar como foi possível elaborar um discurso baseado nos ideais de civilização, humanidade e liberdade e ao mesmo tempo sustentar a hierarquia racial, o branqueamento e a consequente extinção dos afro-brasileiros.

Veríssimo deixou claro que os afrobrasileiros não tinham espaço em um futuro Brasil "civilizado", ou dito de outro modo não valia a pena investir em sua educação. Desse modo, tinham de ser assimilados, à "cultura superior". No entanto, havia uma dúvida sobre a possibilidade dos povos mestiços produzirem civilização. Esta, porém, não sepultou a esperança:

\begin{abstract}
A América é o vastíssimo cadinho em que se fundem hoje as diversas raças e gentes. Porventura sua missão histórica é dar, servindo de campo para o cruzamento de todas elas, unidade étnica à humanidade, e, portanto, nova face às sociedades que hão de viver no futuro. Amplíssimo terreiro aberto às ambições de todo gênero, o Novo Mundo, rompendo com os velhos preconceitos das sociedades tradicionais da Europa toma também o caminho da civilização uma direção nova deixando atrás de si a Ásia e suas antiquíssimas civilizações e a África e a sua secular barbaria. (VERÍSSIMO, 1886, p. 9).
\end{abstract}

Este é o pano de fundo que orientará nossa análise da obra $A$ Educação Nacional de José Veríssimo.

\section{$O$ ideal de branqueamento no projeto educacional de José Veríssimo}

José Veríssimo não estava satisfeito com o estado em que se encontrava a educação no país. De acordo com o autor: “o nosso sistema geral de instrução pública não merece de modo algum o nome de educação nacional. É em todos os ramos [...] apenas um acervo de matérias, amontoadas, [...] sem nexo sem lógica, e estranho completamente a qualquer concepção elevada de pátria” (VERÍSSSIMO, 2013, p. 77). Para o intelectual, uma das tarefas da educação, diferentemente da instrução, era restaurar o povo, conduzi-lo para a civilização: "ora, toda a instrução cujo fim não for a educação cívica e nacional, perde por esse simples fato toda a eficácia para o progresso, para civilização e para a grandeza de um povo" VERÍSSSIMO, 2013, p. 77).

Ainda sobre este tema, na introdução do seu clássico sobre a educação Veríssimo ressaltou a importância do povo neste processo:

Se, como é forçoso reconhecer, o estado moral do Brasil, e ainda seu estado material, é propriamente desanimador e precário e, sobretudo está muitíssimo aquém das justíssimas aspirações dos patriotas e dos gloriosos destinos que lhe antevimos, não há tão pouco negar que nem somente a monarquia e as instituições que lhe eram ministras, senão nós todos somos disso culpados.

É, pois, a nós mesmos, é ao povo, é à nação, que cumpre corrigir e reformar, se quisermos realize a república as bem fundadas auspiciosas esperanças, que alvoreceu nos corações brasileiros.

Para reformar e restaurar um povo, um só meio se conhece, quando não infalível, certo e seguro, é a educação, no mais largo sentido desta palavra (VERÍSSIMO, 2013, p. 63). 
Estas ideias acompanharam Veríssimo durante muito tempo. Seu libelo a favor da educação nacional foi republicado em $1906^{10}$. Em 1908, no prefácio escrito para livro de Paulo Tavares Questões de Ensino podemos ler:

Não há mais necessidade de começar um discurso ou escrito sobre educação e ensino mostrando-lhes as vantagens e a importância. Ainda sem atribuir as virtudes mirificas que foi de moda romântica imputar-lhe, todos parecem de acordo em considerar a questão, como uma das mais relevantes oferecidas a atividade política de qualquer povo.

Num país como o Brasil, ela redobra de importância. A instrução, ou melhor, a educação nacional aqui, não é só um fator de cultura e progresso; mas, e talvez, principalmente, o fator da nossa unidade moral. Não nos iludamos; esta não só é ainda precária e imperfeita fusão dos elementos constitutivos de nossa nacionalidade e até pelas condições geográficas do nosso país, mas é constantemente perturbada, ou está ameaçada de o ser, pela concorrência, aliás necessária e desejável, de novos fatores étnicos e nacionais, diversos dos que contribuíram para nossa primeira formação.

Se é assim, e indubitavelmente, é resulta para nós a necessidade tão urgente quanto imperiosa, de cuidar de nosso ensino público, instrumento de nossa educação nacional, como o único meio legítimo e eficaz de fortificar a nossa cultura, promover o nosso progresso material e moral e operar a fusão, no sentido que nos pareça melhor, dos vários elementos da nação, de modo a constituirmo-nos em um grande povo unido e uno, poderoso e forte ${ }^{11}$ (VERÍSSIMO, 1908 a, p. ix-x).

\footnotetext{
${ }^{10}$ A terceira edição foi publicada somente em 1985. Neste trabalho utilizamos a quarta edição publicada em 2013.

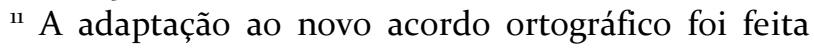
pelo autor.
}

Veríssimo compreendia que a educação devia preparar os indivíduos do ponto de visto moral, intelectual e físico, ou seja, formar o ser humano para vida completa como membro da pátria, da família e da humanidade. A educação moral, também chamada pelo autor de educação do caráter é aquela que "combate a todos os vícios que nos mimam e deprimem, e sobretudo pela educação do sentimento do dever, mais necessário e ouso dizer, mais nobre que a indisciplinada reclamação de direitos" (VERÍSSIMO, 2013, p. 188). Já a educação intelectual era compreendida pelo autor como aquela que "nos dará os elementos indispensáveis ao progresso, à civilização e grandeza das nações.” Além disso, a educação intelectual também nos permitiria defender e prevenir-nos das ilusões de certas doutrinas dos sofistas (VERÍSSIMO, 2013, p. 188). Por fim, à educação física competia "regenerar a nossa raça e nos dar o vigor necessário para a luta material da existência, a consciência do nosso valor pessoal, do qual formará o nosso valor coletivo e se alentarão nossas energias morais." (VERÍSSIMO, 2013, p. 188).

Esta educação nacional descrita por Veríssimo, como pretendia formar um ser humano completo, não era tarefa apenas da escola. A família, a ciência, as religiões, o governo, a política, a arte e a literatura também deveriam ser responsáveis por esta fundamental empreitada (VERÍSSIMO, 2013, p. 188).

Nas citações acima, vimos que Veríssimo fez alusão à fusão das raças e a importância da imigração estrangeira. Na seção anterior apresentamos o entendimento do literato sobre estes conceitos. Seria possível 
relacionar as reflexões efetuadas em outras obras com as reflexões que o pensador realizou sobre a educação? Vejamos o que o próprio Veríssimo tinha a dizer sobre o assunto: "faz um ano, examinando contristado a situação moral do Brasil, no prefácio do livro Estudos Brasileiros, concluía eu essa desanimadora revista por estas palavras [...] (VERÍSSIMO, 2013, p. 61). Em seguida escreveu o pensador paraense:

O Brasil, graças à unidade de raça formado pelo franco cruzamento das três que aqui concorreram no início da nossa constituição nacional, graças a não perturbação desse primeiro resultado pela concorrência de elementos estrangeiros, assim como à unidade da língua, religião, e, em suma, das tradições que mais puderam influir naquele fato, isto é, as portuguesas, têm incomensuravelmente mais acentuado caráter nacional que os Estados Unidos. E semelhante fato, escrevi eu algures ${ }^{12}$, nos assegura um movimento social mais lento é verdade, porém mais firme (VERÍSSIMO, 2013, p. 64).

Está claro que as ideias discutidas em Populações Indígenas e Mestiças da Amazônia e em Estudos Brasileiros orientaram, em grande medida, a obra que ora analisamos. Verificaremos, a seguir, presença das teses da hierarquia racial, branqueamento, mestiçagem eugênica, superioridade europeia, inferioridade africana bem como os conceitos de civilização e progresso em seu clássico sobre a educação.

O intelectual paraense afirmou - em Estudos Brasileiros - que o Brasil foi formado por três raças. Ele retomou esta ideia na

\footnotetext{
${ }^{12} \mathrm{O}$ autor se referia ao que escreveu na página 28 de Populações Indígenas e Mestiças da Amazônia. A citação que apresentamos na página é a introdução desta referência.
}

seguinte passagem: "somos o produto de três raças distintas. Duas selvagens e, portanto, descuidosas e indiferentes como soem ser neste estágio da vida, e uma em rápido declínio depois de uma gloriosa, brilhante e fugaz ilustração" (VERÍSSIMO, 2013, p. 92).

Também asseverou que os africanos eram uma raça bárbara, feroz e responsável pelas consequências funestas da escravidão na sociedade brasileira e pelo lastimável estado em que esta se encontra. Para o autor a escravidão fez com que os brasileiros se degradassem e tivessem aversão pelo trabalho. Estas reflexões apareceram novamente no seu libelo educacional. Nas palavras do autor:

Não é possível exagerar os males que nos trouxe a escravidão. Durante trezentos anos refestelamo-nos no trabalho, primeiro do índio depois do negro. Queiram os destinos do Brasil que não nos seja preciso tanto tempo para livrarmo-nos de uma vez do funestíssimo veneno da maldita instituição, que pela indefectível lei da justiça na história, que quer todo o erro traga em si o seu castigo, ainda hoje nos pesa e avexa! Não somente abolindo como degradando o trabalho, a escravidão consumou em nós a morte de todas as energias, já enfraquecidas pelo clima e pela hereditariedade.

Extinta a escravidão índia, o africano alegre, descuidoso, afetivo, meteu-se com sua moralidade primitiva de selvagem, seus rancores de perseguido, suas ideias e crenças fetichistas, na família, na sociedade, no lar. Invadiu tudo e imiscuiu-se em tudo. Embalou a rede da sinhá, foi o pajem do sinhô-moço, o escudeiro do sinhô. Ama, amamentou todas as gerações brasileiras; mucama, a todas acalentou; homem para todas trabalhou; mulher a todas se entregou. Não havia casa onde não existisse um ou mais moleques, um ou mais curu- 
mins, vítimas consagradas aos caprichos do nhonhô. Eram-lhe o cavalo, o leva pancadas, os amigos os companheiros, os criados.

As meninas, as moças, as senhoras tinham para os mesmos misteres, as mucamas, crioulas e mulatas.

Nunca se notou bastante a depravada influência deste peculiar tipo brasileiro, a mulata, no amolecimento do nosso caráter. "Esse fermento afrodisismo pátrio" como lhe chama o sr. Silvio Romero, foi um dissolvente da nossa virilidade física e moral (VERISSIMO, 2013, p. 94$) \cdot{ }^{13}$

Pelo excerto acima podemos perceber claramente a localização psicológica ${ }^{14}$ do autor. Além de marginalizar os africanos em sua própria história, Veríssimo se referia a eles como se não fossem brasileiros. A aparente exceção - que não valia para as mucamas e crioulas - é sua referência à mulata. Isto porque a tradição nacional transformou, e erotizou, esta mulher afro-brasileira em produto de exportação nacional. Como bem demonstrou Abdias do Nascimento, a política de branqueamento teve como um dos seus pilares o estupro das afrobrasileiras, porém elas é que são consideradas depravadas, responsáveis pelo amolecimento do nosso caráter e pela perda de nossa virilidade física e moral! Nascimento constantemente lembrava em seus textos do

\footnotetext{
13 Os itálicos e as aspas são do original.

${ }^{14}$ O conceito de localização psicológica foi desenvolvido pelo intelectual afro-estadunidense Molefi Kete Asante e é um dos conceitos centrais de sua teoria afrocêntrica. Por meio deste conceito é possível verificar a perspectiva que orienta o trabalho de qualquer pesquisador. Podemos avaliar se uma pessoa está localizada em uma posição central em relação ao mundo africano pelo modo como ela se relaciona com a informação africana. Se ela se refere aos africanos como "outros", percebemos que os vê diferente de si mesma. (ASANTE, 2009, p. 96).
}

adágio popular utilizados pelas elites dirigentes que de forma lapidar sintetiza este desprezo pelas afro-brasileiras: branca para casar, negra para trabalhar, mulata para fornicar.

Como para Veríssimo os africanos possuíam uma moralidade primitiva, eram fetichistas e imiscuíram a selvageria na família e na sociedade brasileira - além, de servir, com muito bom grado, de saco de pancadas do nhonhô e as amas e mucamas amamentarem e acalentarem todas as gerações brasileiras - podemos imaginar que tipo de vícios a educação moral proposta pelo literato visava combater:

Essa educação, claro está, deve começar, senão desde o berço, conforme quereriam alguns, ao menos desde os três anos, na família. Nenhum meio mais próprio e mais conveniente do que esse para encerrar a educação do caráter da criança, e lançar na sua alma os gérmens que hão de desenvolver-se mais tarde no adolescente e no homem. A constituição da família brasileira, profundamente viciada pela escravidão, ressente-se ainda de graves senões, entre os quais o mais saliente é a ausência da ação feminina. Os antigos hábitos portugueses de proscrever a mulher não só da sala, mas de todas as relações sociais e domésticas, adotamo-los piorando-os. [...]. É incalculável a influência que as mucamas tiveram na família brasileira ${ }^{15}$, como foi profundíssima sua ação deletéria. E este isolamento da brasileira não era apenas, por assim dizer, material, senão moral, pois criado num bruto respeito do marido, não tinham suas relações caráter algum de íntimo e igual convívio (VERÍSSIMO, 2013, p. 100). ${ }^{16}$

\footnotetext{
${ }^{15}$ Os itálicos são nossos.

${ }^{16}$ Os itálicos são nossos.
} 
Veríssimo mais uma vez deixou claro a oposição entre ser mucama e ser brasileira. A ação daquela, no entender do autor, foi deletéria na família nacional. Vale a pena acompanhar o raciocínio desenvolvido pelo intelectual para chegar a esta conclusão. Veríssimo estava preocupado com o fato de as mulheres brasileiras não ocuparem o seu papel na educação dos filhos, pois para o autor a ação delas no que dizia respeito à família é maior do que a do homem. Sendo assim lamentou o fato de as famílias brasileiras terem adotado e piorado os hábitos dos portugueses de proscrever as mulheres da vida familiar, das relações sociais e domésticas, bem como o fato das esposas brasileiras demonstrarem um respeito bruto por seus maridos tratando-os por senhor. Veríssimo afirmava que as mães brasileiras eram fracas e como evidência para esta afirmação dizia que não era raro ver uma criança de três ou quatro anos ainda no colo, que elas não faziam seus filhos acordar cedo, comer na hora e dar-lhes banho frio (VERÍSSIMO, 2013, p. 101). E de quem era a responsabilidade por este estado de coisas: da mucama! É espantoso que a discussão da formação do caráter dos brasileiros, feita pelo literato, não tenha passado pela investigação dos valores que levaram a existência de mucamas e se estes ainda continuavam presentes na sociedade brasileira, ou melhor, em nossa elite intelectual e econômica.

Adotando a ciência eurocêntrica e contrariando todo o saber sobre o matriarcado como uma das principais características das sociedades africanas, aduzia o pensador paraense: “junte-se a estes hábitos herdados de Portugal [...], a influência dire- ta e indireta de duas raças selvagens, nas quais segundo a lei etnológica, a mulher tem sempre um papel mais secundário e ter-se-á claramente explicada a posição da mulher brasileira" (VERÍSSIMO, 2013, p. 101).

Se nossa explicação parece exagerada, vejamos o que Veríssimo tinha a dizer sobre a influência das afro-brasileiras no processo de educação física dos filhos das "famílias brasileiras" - lembremos que o autor sustentava que uma das tarefas principais desta modalidade de educação era regenerar a nossa raça:

Nada obstante a meiguice e carinho da mãe brasileira - o que prova que até as virtudes se querem esclarecidas - a nossa educação infantil, física como espiritual, é inteiramente primitiva e empírica.

Os nossos filhos eram entregues aos cuidados das escravas, cujo leite quase sempre eivado de vícios que mais tarde lhes comprometeria a saúde, principalmente os alimentava. Eram as mucamas, escravas ou ex-escravas, - e isto basta para indicar seu valor como educadoras - que de fato dirigiam a sua primeira educação física, pois eram elas quem superintendia na alimentação, nos passeios, no vestuário e nos demais atos da vida infantil. Não era raro ver meninos de oito e mais anos dormindo na mesma rede que a mucama do seu serviço que, em geral extremamente amorosa e afeiçoada a eles, não sabia recusar-lhes nada, nem ainda aquilo que evidentemente lhes podia comprometer a saúde. O que tinham de enervantes semelhantes e costumes, que, sem mentir, se não podem dizer lindos, não escapará a ninguém.

Estes hábitos exigem ser corrigidos e modificados de acordo com os ensinamentos da higiene e pedagogia infantil (VERÍSSIMO, 2013, p. 113-114). ${ }^{17}$

\footnotetext{
${ }^{17}$ Os itálicos são nossos.
} 
O que dizer das palavras do autor? O leite das afro-brasileiras eivado de vícios que comprometeria a saúde de nossos filhos? Utilizar como prova da incapacidade de educar das afro-brasileiras o fato de terem sido escravizadas? Acaso ser escravocrata atestaria a melhor condição destes para ser educador ou educadora? Como se não bastasse esta caracterização grosseira, Veríssimo reprovava as mucamas porque não diziam "não" para os filhos de seus senhores! Seria possível imaginar uma mulher afro-brasileira, na condição de escrava, recusar algo para crianças - em particular os meninos - que tinham afro-brasileiros como saco de pancadas? Se ela tomasse esta atitude - e muitas tomaram - ainda seria mucama? Escaparia das torturas a que os afro-brasileiros foram submetidos durante este nefasto período da história brasileira? É importante observar que o literato estava preocupado com os efeitos que o sistema escravocrata provocou nas elites brasileiras. Não se preocupou em avaliar os valores que permitiram mais de trezentos anos de holocausto, assim como achava normal a política de branqueamento para solucionar "o problema negro”. Não seriam estas importantes questões a serem investigadas, visto que o autor estava refletindo sobre a formação do caráter nacional e a eliminação dos vícios que nos deprimiam? A resposta a estas questões seria afirmativa se as reflexões do literato não fossem orientadas pelo eurocentrismo e pelo racismo. Voltando a analisar a importância da educação física para o pensador a passagem abaixo é reveladora do papel desta modalidade educacional:

\begin{abstract}
A educação física no Brasil é, em todo rigor da expressão um problema nacional.

Nossa raça, sentem-no todos, se enfraquece e abastarda sob a influência de um clima deprimente, piorada pela falta de higiene, pela carência de exercício, pela privação da atividade. Uma propaganda que não quero, como o sr. Sílvio Romero, chamar antipatriótica, mas que certo não viu o interesse do Brasil senão por um lado, atraiu determinadas regiões do país uma imigração, forte pelo número e pelo vigor, e que melhor valera disseminada por ele todo. Essa propaganda continua, e certo continuará a afluir, e em maior número, a imigração, principalmente alemã e italiana. A luta entre essa gente, incomparavelmente mais forte, e nós, não pode ser duvidosa. O campo de combate será primeiramente o das atividades físicas, aquele que exige maior soma de robustez, de força e de saúde, o comércio, a indústria, os ofícios, a lavoura.

É, portanto, indispensável prepara-nos para, sem recorrer a meios que não consente a nossa civilização, não nos deixarmos abater e esbulhar, a fim de que esta terra, que nossos antepassados criaram e civilizaram, e cuja futura grandeza prepararam, seja principalmente nossa (VERÍSSIMO, 2013, p. 122).
\end{abstract}

Dada nossa exposição até aqui a referência acima é autoexplicativa. Tratemos agora da concepção de educação intelectual defendida pelo literato. Esta, de acordo com Veríssimo, nos daria os elementos fundamentais para o progresso, a civilização. A civilização que o educador tem em mente é a ocidental. Este fato, por si mesmo, não constitui um problema. Porém, em um projeto assimilacionista, o que significa para os afro-brasileiros serem "assimilados" por esta civilização? Significa rejeitar a história e cultura africana para abraçar a história e cultura europeia. Tomemos como exemplo 
Machado de Assis. Observe como nosso educador, ao homenageá-lo por ocasião de seu falecimento, retratou o intelectual afrobrasileiro:

São tanto mais de admirar e até de maravilhar, estas qualidades de medida, de tato, de bom gosto, de harmonia, em suma de elegância, na vida e na arte de Machado de Assis, que elas são justamente as mais alheias ao nosso gênio nacional e muito particularmente aos mestiços como ele. O próprio destes é serem descomedidos, exuberantes, filauciosos, exagerados. Sob este aspecto, Machado de Assis era a negação viva da falaz teoria da raça. Mulato, foi de fato um grego da melhor época, pelo seu profundo senso de beleza, pela harmonia da sua vida e pela eurritmia de sua obra (VERÍSSIMO, 29 de outubro, de 1908). ${ }^{18}$

O pensador que atestou a falsidade da teoria racial é o mesmo que afirmou que bom gosto, elegância e harmonia eram alheios aos mestiços. Por causa deste ideário, Joaquim Nabuco ${ }^{19}$ ficou "arrepiado" e "recomendou" que Veríssimo não se referisse ao intelectual afro-brasileiro como mula-

\footnotetext{
${ }^{18}$ A adaptação ao novo acordo ortográfico é de nossa responsabilidade.

${ }^{19}$ Em uma carta enviada a José Veríssimo, Joaquin Nabuco escreveu: Seu artigo no jornal está belíssimo, mas essa frase causou-me arrepio: 'Mulato, foi de fato um grego da melhor época'. Eu não teria chamado o Machado mulato e penso que nada lhe doeria mais do que essa síntese. Rogo-lhe que tire isso quando reduzir os artigos a páginas permanentes. A palavra não é literária e é pejorativa, basta ver-lhe a etimologia. $O$ Machado para mim era um branco, e creio que por tal se tornava; quando houvesse sangue estranho, isso em nada afetava a sua perfeita caracterização caucásica. Eu pelo menos só vi nele o grego. O nosso pobre amigo, tão sensível, preferiria o esquecimento à glória com a devassa sobre suas origens (Carta a José Veríssimo, 25 de novembro de, 1908).
}

to. ${ }^{20}$ Podemos perceber claramente a arrogância e prepotência de Veríssimo e Nabuco, que era, e ainda é em grande medida compartilhada pelas elites brasileiras, ao tentar impor a identidade branca e ocidental à Machado de Assis e, por extensão aos afro-brasileiros. Como bem observou Abdias do Nascimento comentando a carta do jurista pernambucano: "num detalhe, pelo menos, Nabuco estava com a razão: mulato é vocábulo pejorativo, e a designação correta é a palavra negro. Um negro ser chamado de grego é ainda muito pior. Sangue grego, sim, é irremediavelmente estranho à realidade negra ou brasileira” (NASCIMENTO, 1980, p. 112). Mas a elite intelectual brasileira era confiante que o futuro da nação seria branco e ocidental.

Dado o exposto nesta seção parece não haver dúvidas quanto à presença e influência do ideal de branqueamento no projeto educacional que José Veríssimo ofereceu à nação.

\footnotetext{
${ }^{20}$ A reprimenda surtiu efeito. Este artigo não entrou nas obras literárias publicadas por Veríssimo. Sobre este assunto ver o belíssimo texto de Ana Maria Gonçalves, A caixa, Machado de Assis e o branqueamento do Brasil disponível em: http://www.revistaforum.com.br/idelberavelar/2011/ og/18/a-caixa-economica-federal-a-politica-dobranqueamento-e-a-poupanca-dos-escravos-porana-maria-goncalves/ acesso em 21/o6/2017 e o texto de Silvia Maria Azevedo, $O$ ano da morte de Machado de Assis disponível em: http://www.unesp.br/aci/jornal/232/supled.php acesso em: 21/o6 de 2016.
} 


\section{Considerações Finais}

$\mathrm{O}$ ideal de branqueamento, embora desmascarado pelos intelectuais afrobrasileiros, ainda continua presente no imaginário nacional e, por consequência, em nosso sistema de ensino. ${ }^{21}$ Este fato contribui para o pouco estudo existente sobre o papel desempenhado pela escola na implementação e consolidação da política de branqueamento da nação. O mesmo fenômeno, como não poderia deixar de ser, ocorre no que diz respeito a produção sobre o projeto educacional de José Veríssimo. A versão mais recente de sua obra $A$ Educação Nacional contém uma introdução escrita pelo professor José Murilo de Carvalho. Nestas quinze páginas não encontramos uma única referência sobre eurocentrismo e o racismo do educador. Já com o livro José Veríssimo: Raça, Cultura e Educação, organizado pela professora Sonia Araújo ocorre algo diferente. O livro é resultado da pesquisa dela e de mais quatro professores da Universidade Federal do Pará e tem como objetivo:

[...] analisar os escritos de José Veríssimo, por meio do estudo de enunciados sobre cultura e educação, visando compreender o preconceito e a discriminação étnica tão fortemente presente no Brasil no século XX e, assim, entender o sentido que têm as políticas de inclusão no campo da educação propostas hoje pelo

\footnotetext{
${ }^{21}$ Jerry Dávila, no último capítulo de Diploma da Brancura (p. 355), no qual analisa o persistente - e atual - fascínio brasileiro pela raça, escreve: "a eugenia perdeu a legitimidade científica após o final da Segunda Guerra Mundial, mas as instituições, práticas e pressupostos a que ela deu origem - na verdade, seu espírito - sobrevivem.”.
}

Estado brasileiro. (ARAÚJO, 2007, p.12) 22

Esta obra é um oásis no meio de um deserto - no que diz respeito às questões aqui tratadas. Entretanto, nos cinco artigos que compõem o livro não há reflexão que articule as relações entre o eurocentrismo, a política de embranquecimento da nação e seu projeto de educação nacional. Aliás, o que é um paradoxo, não há uma análise detalhada do projeto de branqueamento delineado pelas elites brasileiras.

Diante desta situação, é forçoso concluir que para os afro-brasileiros que ingressam e frequentam o sistema educacional brasileiro, em grande medida, o branqueamento ainda é a única opção. Assim, para mantermos nossa integridade cultural é urgente construir um modelo educacional que valorize e respeite a cultura, a história e as tradições africanas e afro-brasileiras.

\footnotetext{
${ }^{22}$ Os itálicos são do original.
} 


\section{Referências}

ARAÚJO, Sonia M. S. (org.). José Veríssimo: Raça, Cultura e Educação. Belém: EDUFPA, 2007.

ASANTE, Molefi Kete. Afrocentricidade: Notas sobre uma posição disciplinar. In: Elisa L. Nascimento (org.). Afrocentricidade uma abordagem epistemológica inovadora. São Paulo: Selo Negro, 2009, p. 93-110.

DÁVILA, Jerry. Diploma de Brancura: Política Social e Racial no Brasil 1917-1945. São Paulo: UNESP, 2006.

MOORE, Carlos. Racismo \& sociedade: novas bases epistemológicas para entender o racismo. Belo Horizonte: Mazza Edições, 2007.

NABUCO, Joaquim. Carta a José Veríssimo de 25 de novembro de 1908.

NASCIMENTO, Abdias. O Quilombismo. Petrópolis: Vozes, 1980.

O Brasil na Mira do Pan Africanismo. Salvador: EDUFBA: CEAO, 2002.

NASCIMENTO, Elisa L. O Sortilégio da Cor identidade, raça e gênero no Brasil. São Paulo: Selo Negro, 2003.

SKIDMORE, Thomas E. Preto no Branco - Raça e Nacionalidade no Pensamento Brasileiro. Rio de Janeiro: Paz e Terra, 1989.

VERÍSSIMO, José. Cenas da vida amazônica com estudos sobre as populações indígenas e mestiças da Amazônia. Lisboa: Tavares Cardoso, 1886.

. Estudos Brasileiros, 1877-1885. Pará: Tavares Cardoso, 1889.

. José. O País Extraordinário. In: Jornal do Comércio, o4 de dezembro de 1899.

onal, 1908a. . Prefácio. In: Paulo Tavares. Questões de Ensino. Rio de Janeiro: Imprensa Nacioutubro de 1908b.

. Machado de Assis Impressões e Reminiscências. In: Jornal do Comércio, 29 de

A Educação Nacional. Rio de Janeiro: Topbooks; Belo Horizonte: Puc Minas, 2013.

Recebido em: 27/06/2017

Aprovado em: 31/10/2019 